\title{
Rancang Bangun Sistem Informasi Pendataan Penduduk Dikantor Kelurahan Kotaratu Kabupaten Ende
}

\author{
Siti Soraya ${ }^{1}$, Ferdinandus Lidang Witi $^{2 *}$
}

\author{
${ }^{1}$ Sistem Informasi, Teknologi Informasi, Universitas Flores, Ende, Indonesia \\ ${ }^{2}$ Sistem Informasi, Teknologi Informasi, Universitas Flores, Ende, Indonesia \\ Email: ${ }^{1}$ SitiSoraya1412@gmail.com, ${ }^{2 *}$ ferdylidang2017@gmail.com
}

\begin{abstract}
Currently, not many urban vilages in Indonesia, especially in Ende Regency, make nlne population data reports. With the existing benefits and conveniences, this system should be developed by each keurahan.in this case, it is in line with advances in information and communication technology such as internet and web tecnologies that support the process input and output data quickly and accurately, especially in collecting data on residents in the Kota ratu village. In the current pandemic (Covid-19), information technology is very much needed, because the government implements large-scale sosial rules or restrictions in the context of handling Covid-19. In this social restriction effort, the Indonesian government has also limited activities outside the home. As we know, population data collection is generaly done manually, i.e. village Officers come to residents' homes to collect data so that the time required becomes inefficient. This study aims to design a population dat collection information system at the Kota Ratu District Office, Ende Regency, so that it can make it easier for village employees to carry out population data collection processes and monthly reports. The software development method used is the waterfall method. Data collection techniques in this study used interviews, obsevation and literature study. This research can also produce a population data collection information system that can present information quicky and efficiently and can present the necessary reports.
\end{abstract}

Keywords: Population Data Collection, Information System, Website

\begin{abstract}
ABSTRAK
Sekarang ini belum banyak kelurahan di indonesia khususnya di Kabupaten Ende membuat laporan data penduduk bersifat online. Dengan manfaat dan kemudahan yang ada, sudah seharusnya sistem ini dikembangkan oleh tiap-tiap kelurahan. Dalam hal ini sejalan dengan kemajuan teknologi informasi dan komunikasi seperti teknologi internet dan web yang mendukung proses input dan output data secara cepat dan akurat, khususnya dalam mendata penduduk di kelurahan kota ratu. Di masa Pendemi (Covid 19) sekarang ini, teknologi informasi sangat dibutuhkan, karena pemerintah menerapkan aturan atau pembatasam sosial berskala besar dalam rangka penanganan Covid-19. Dalam usaha pembatasan sosial ini pemerintah indonesia juga telah membatasi kegiatan diluar rumah. Seperti yang kita ketahui, pendataan penduduk pada umumnya dilakukan secara manual yaitu Petugas Kelurahan mendatangi rumah warga untuk melakukan pendataan sehingga waktu yang diperlukan menjadi tidak efisien. Penelitian ini bertujuan untuk Rancang Bangun Sistem Informasi Pendataan Penduduk di Kantor Kelurahan Kota Ratu Kabupaten Ende, sehingga dapat memudahkan pegawai kelurahan dalam melakukan proses pendataan penduduk dan laporan bulanan. Metode pengembangan perangkat lunak yang digunakan adalah metode waterfall. Teknik pengumpulan data pada penelitian ini menggunakan wawancara, observasi dan studi pustaka. Penelitian ini jua dapat menghasilkan sebuah sistem informasi pendataan penduduk yang dapat menyajikan informasi secara cepat dan efisien serta dapat menyajikan laporan yang diperlukan.
\end{abstract}

Kata Kunci : Pendataan Penduduk, Sistem Informasi, Website.

Diterima Redaksi: 15-09-2021 | Selesai Revisi: 05-10-2021 | Diterbitkan Online: 19-10-2021 


\section{Pendahuluan}

Pada era globalisasi saat ini komputer sangat berperan penting dalam kehidupan manusian untuk memenuhi kebutuhan informasi yang semakin meningkat [1]. Adanya kecanggihan teknologi saat ini dapat mempermudah pekerjaan yang akan dilakukan, kita juga dapat mencari informasi yang kita butuhkan serta kita dapat memperluas jaringan komunikasi menggunakan teknologi. Salah satu yang banyak digunakan adalah komputer dengan danya komputer, informasi yang didapat lebih akurat tepat dan cepat. Kita dapat menggunakan teknologi komputer untuk menyimpan, mengorganisasi dan melakukan pengambilan dari berbagai data yang kita miliki. Kemajuan teknologi informasi ini tentunya membuat banyak perubahan dalam kehidupan sehari-hari seperti perubahan dalam bidang pertanian, pendidikan, komunikasi dan lain sebagainya. Dengan segala kecanggihan komputer saat ini banyak perusahaan atau lembaga yang memanfaatkan teknologi tersebut. Saat ini, Kelurahan di Indonesia khususnya di Kabupaten Ende dalam mendata penduduk belum banyak bersifat online. Di masa Pendemi (Covid 19) sekarang ini, teknologi informasi sangat dibutuhkan, karena kotaratu yang dijalankan selama ini, dan pembuatan pemerintah menerapkan aturan atau pembatasam sosial Surat keterangan (Domisili, Kelahiran, Meninggal, berskala besar. Dalam usaha pembatasan sosial ini Pindah Penduduk). Meyode Studi Pustaka peneliti pemerintah indonesia juga telah membatasi kegiatan mendapatkan informasi tambahan yang relevan dengan diluar rumah. Seperti yang kita ketahui, pendataan penelitian ini dari referensi jurnal, dan artikel.

penduduk pada umumnya dilakukan dengan cara pegawai kelurahan mendatangi rumah warga untuk mendata. Ditengah wabah covid-19 saat ini, hal tersebut tentu menjadi sangat berbahaya sebab bisa menimbulkan kerumunan banyak orang di sekeliling rumah warga. Kantor Lurah Kota Ratu merupakan salah satu instansi Pemerintah dibawah naungan Pemerintah Kabupaten Ende dengan Pemanfaatan teknologi komputer pekerjaan tentang pengolahan administrasi sudah cukup baik, namun dalam pengelolaan data penduduk masih dilakukan secara manual yaitu Petugas Kelurahan mendatangi rumah warga untuk melakukan pendataan sehingga waktu yang diperlukan menjadi tidak efisie. Sistem pendataan penduduk menggunakan media kertas sehingga rentan mengalami kerusakan atau hilang sehingga pekerjaan menjadi tidak efektif. Perekapan atau laporan jumlah data penduduk di kantor kelurahan juga masih bersifat manual (file excel) sehingga ketika membuat perekapan laporan penduduk tiap bulan harus mengetik ulang dikarenakan file excel data penduduk bulan lalu tertendes dengan file yang diketik dan rekapan data nama-nama penduduk datang, meninggal, dan penduduk pindah masih dalam bentuk buku register kelurahan. Jumlah penduduk yang ada diwilayah Kota Ratu pada bulan Mei 2021 berjumlah 5.248 jiwa dan penduduk yang datang mengurus Surat Keterangan di Kantor Kelurahan Kota Ratu perbulan berjumlah 137 Surat Keterangan. Dikarenakan jumlah data warga yang sangat banyak sehingga sering terjadi kesalahan dalam perekapan data karena data penduduk masih dalam bentuk tumpukan kertas. Agar tercipta suatu yang memadai untuk mengatasi permasalah yang dihadapi oleh kelurahan, maka cara untuk mengantisipasi masalah tersebut perlu dibuat sistem di kelurahan untuk mempermudah pegawai kelurahan dalam mengelolah atau pendataan penduduk (data lahir, pendatang, pindah dan meninggal) sehingga lebih efektif dan efisien dan proses informasi laporan penduduk dapat lebih cepat diolah dan diterima oleh pihak Kecamatan Ende Utara.

\section{Metode Penelitian}

Metode pengumpulan data yang dilakukan dengan cara Observasi, wawancara dan studi pustaka. Pada metode observasi ini dilakukan peninjauan danpenelitian langsung pada tempat penelitian untuk mengumpulkan data atau informasi yang dibutuhkan. Observasi ini dilakukan kepada Pegawai kelurahan kota ratu dan masyarakat. Metode wawancara peneliti melakukan tanya jawab pegwai kelurahan tentang proses pendataan penduduk di kantor kelurahan

Metode pengembangan perangkat lunak yang digunakan dalam penelitian ini adalah menggunakan metode waterfall. Metode waterfall terdiri dari 5 tahap antara lain sebagai berkut [2] :

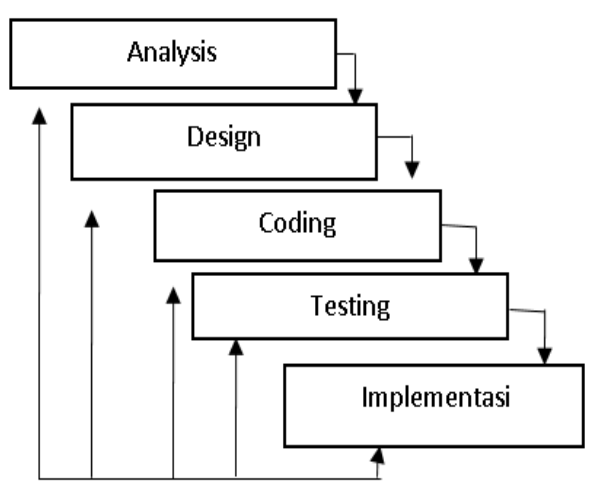

Gambar 1. Metode Waterfall

Pada tahap analysis peneliti menganalisa alur sistem secara garis besar, kemudian menganalisa data yang digunakan agar dapat implementasi kedalam sistem yang akan dibangun. Tahap Design peneliti merancang tampilan sistem dari sebuah sistem yang akan dibangun berdasarkan hasil analisis yang akan ditahap sebelumnya mulai dari model aplikasi, dengan menentukan rancangan secara luas dan

DOI: $10.54259 /$ satesi.v1i2.15

Lisensi: Creative Commons Attribution 4.0 International (CC BY 4.0) 
menarik. Pada tahap Coding, proses coding atau merupakan bahan untuk perbandingan untuk untuk pembuatan software menggunakan bahasa merancang yang baru. Ide untuk melengkapi sistem pemograman PHP dan basis data MYSQL. Hasil dari informasi timbul karena adanya permasalahan tentang tahap ini adalah program komputer sesuai dengan pendataan penduduk di kelurahan kota ratu masih desain yang telah dibuat pada tahap desain. Tahap bersifat manual sehingga pekerjaan ini memakan waktu Testing peneliti melakukan penggabungan modul yang cukup lama dikarenakan pertugas harus merekap yang sudah dibuat pada tahap sebelumnya. Pengujian data penduduk kembali menggunakan microsoft excel. bertujuan untuk mengetahui apakah software yang Untuk lebih mempermudah perancangan sistem, perlu dibuat telah sesuai dengan desainnya dan apakah dilihat permasalahan dari sistem yang sedang berjalan masih terdapat kesalahan atau tidak. Tidak menutup saat ini dengan memperhatikan aliran informasi yang kemungkinan sebuah perangkat lunak mengalami dimulai dari pihak kelurahan mendatangi rumah warga. perubahan ketika sudah dikirim ke user. Perubahan bisa terjadi karena adanya kesalahn muncul dan tidak 3.2 Analisis Sistem yang Diusulkan terdeteksi saat pengujian sehingga perlu dilakukan maintenance.

\section{Hasil dan Pembahasan}

Sistem yang diusulkan dalam pendataan penduduk di kantor kelurahan kota ratu dapat digambarkan dalam bentuk flowchart.

\subsection{Analisis Sistem Berjalan}

Sistem yang sedang berjalan dalam pendataan penduduk kantor kelurahan kota ratu dapat digambarkan dalam bentuk flowchart.

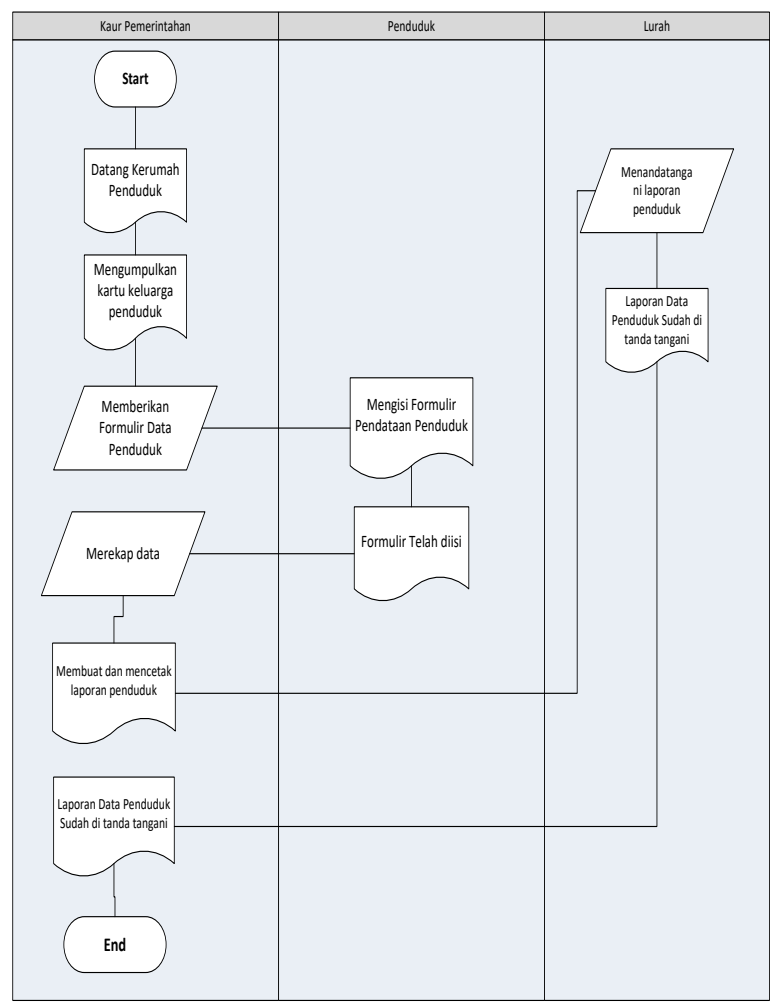

Gambar 2. Flowchart Sistem Yang Berjalan

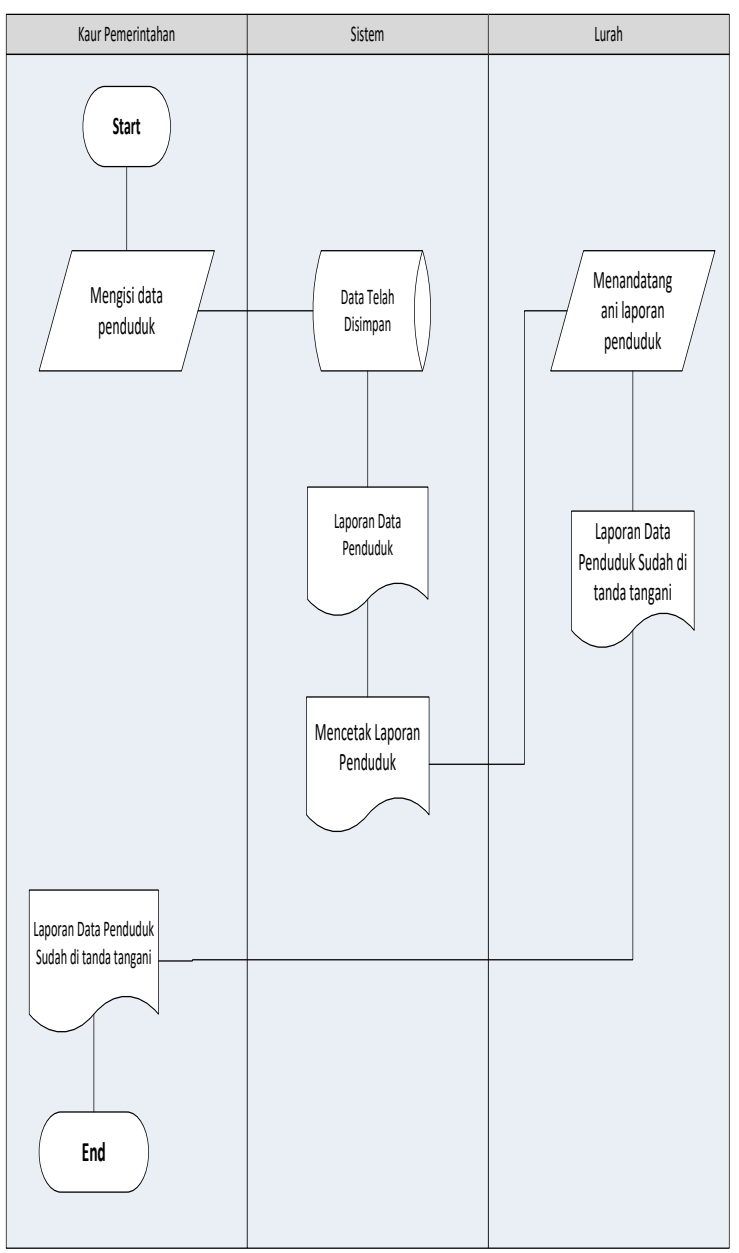

Gambar 3. Flowchart Sistem Yang diusulkan

Sebelum dilakukan perancangan terhadap sistem baru, perlu adanya gambaran mengenai sistem yang ada atau sistem yang sedang berjalan. Dalam hal ini untuk memudahkan didalam melakukan perancangan sistem baru tersebut sehingga apa yang diinginkan dapat berjalan dengan baik. Sehingga sistem yang lama

\subsubsection{Usecase Diagram}

Berikut ini merupakan Usecase Disgram Sistem Pendataan Penduduk yang dirancang untuk kantor lurah kota ratu kecamatan ende utara kabupaten ende. 


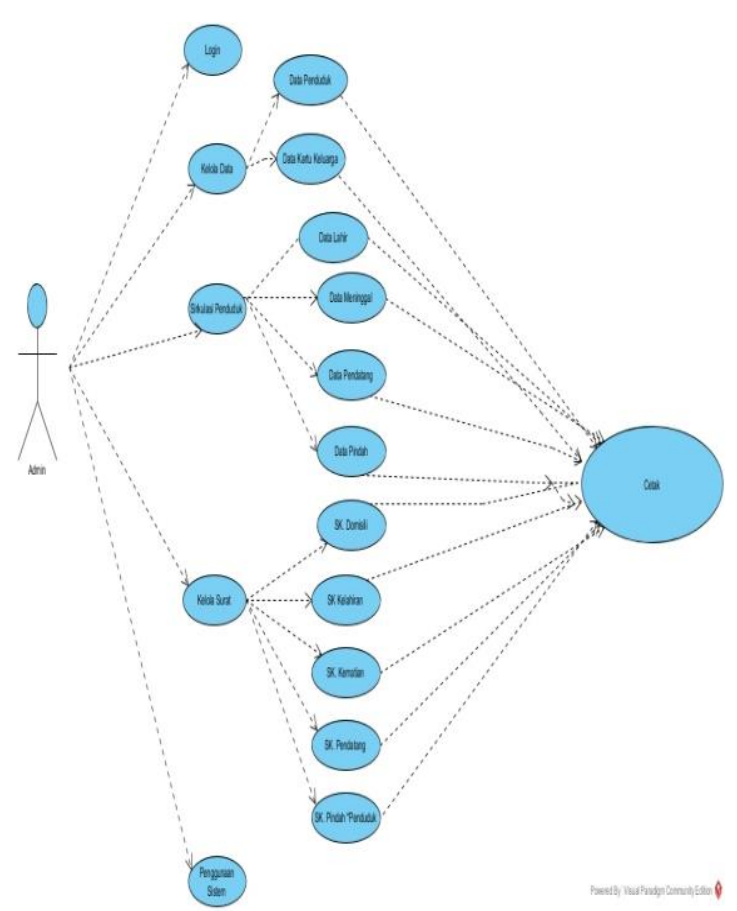

Gambar 4. Usecase Diagram Admin

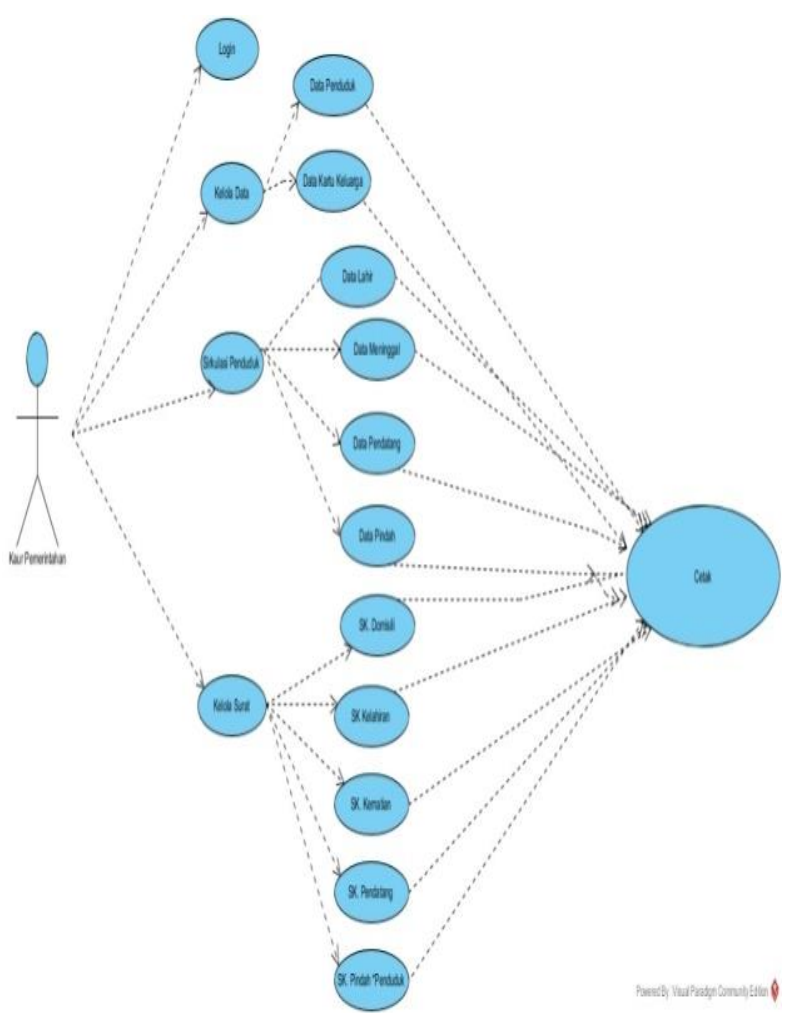

Gambar 5. Usecase Diagram Kaur Pemerintahan

Gambar diatas merupakan gambaran dari fungsionalitas sistem yang akan dibangun yang terdiri dari dua pengguna yaitu admin dan kaur/kasie pemerintahan. Masing-masing pengguna memiliki fungsionalitas yang berbeda dengan pambatas hak akses.

\subsubsection{Activity Diagram Login}

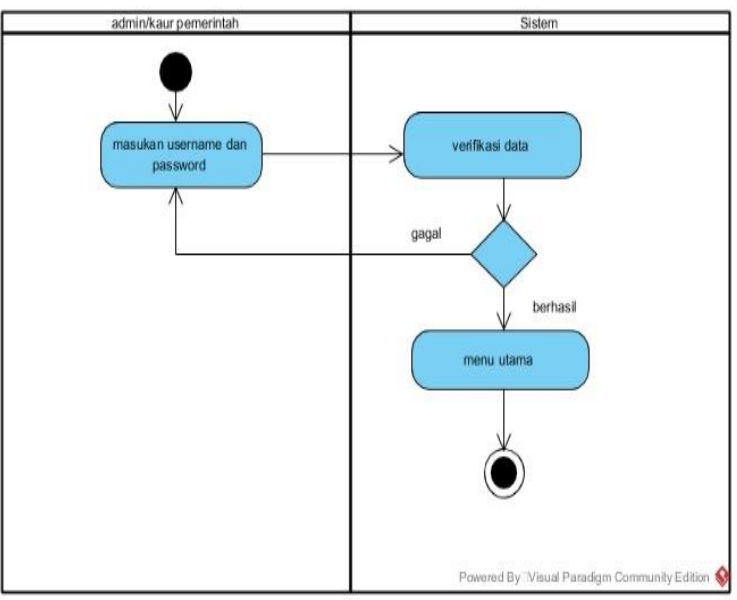

Gambar 6. Activity Diagram Login

Proses login merupakan proses utama yang dilakukan admin. Dimana admin harus memasukan username dan password selanjudnya diverifikasi.

\subsubsection{Activity Diagram Data Penduduk}

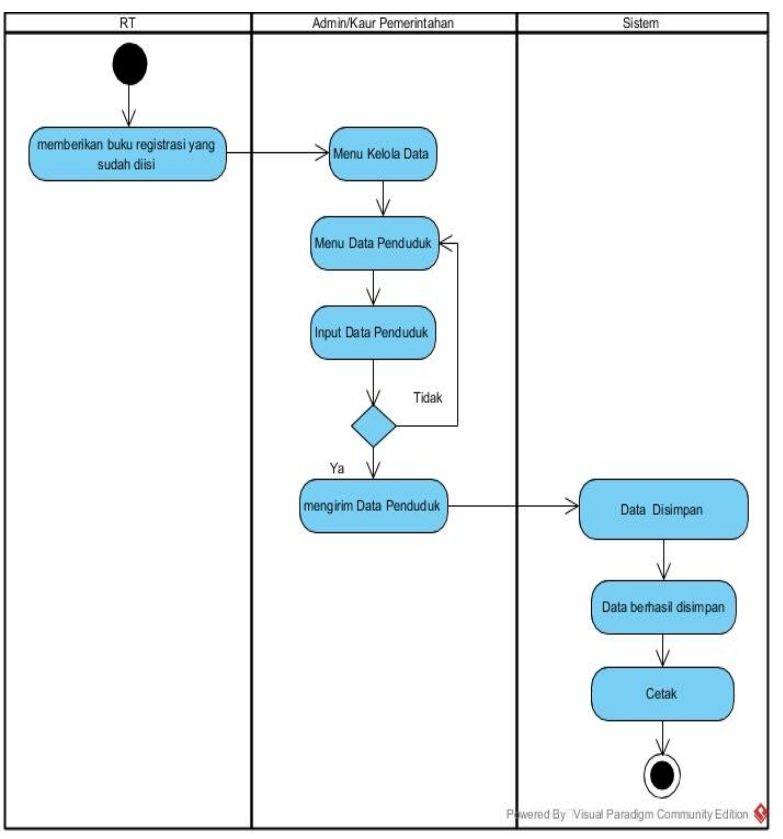

Gambar 7. Activity Diagram Data Penduduk

RT memberikan Buku registrasi yang sudah diisi ke Admin/kaur pemerintahan dan membuka menu kelolah data, kemudian mengklik pada menu data penduduk, lalu menginput data penduduk, jika benar maka data penduduk tersebut dikirim ke database akan disimpan. Kemudian data penduduk dapat kita mencetak laporan data penduduk. Jika salah maka harus memeriksa kembali data penduduk yang diinput pada menu data penduduk.

DOI: $10.54259 /$ satesi.v1i2.15 


\subsubsection{Activity Diagram Data Kartu Keluarga}

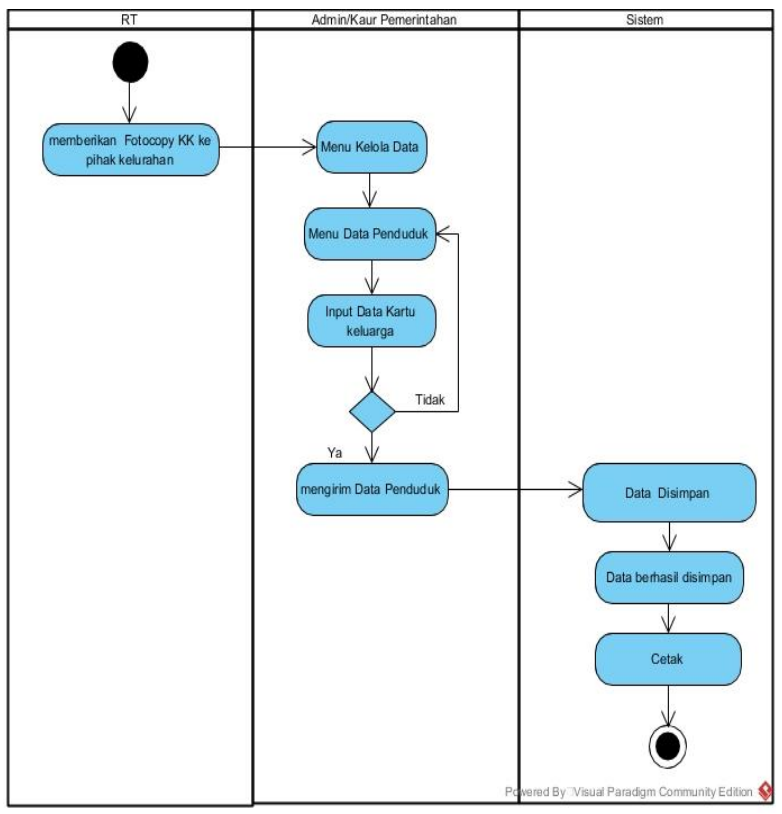

Gambar 8. Activity Diagram Data Kartu Keluarga

RT memberikan FC KK seluruh warga keoada admin/kaur pemerintahan kemudian admin membuka menu kelolad data, mengklik pada menu data kartu keluarga, kemudian admin memasukan data kartu keluarga, kemudian memasukan data KK, jika benar maka data tersebut dikirim ke database untuk disimpan. Kemudian admin dapat mencetak laporan data KK. Jika salah maka harus memeriksa kembali data KK yang diinput pada menu tersebut.

\subsubsection{Activity Diagram Data Kelahiran}

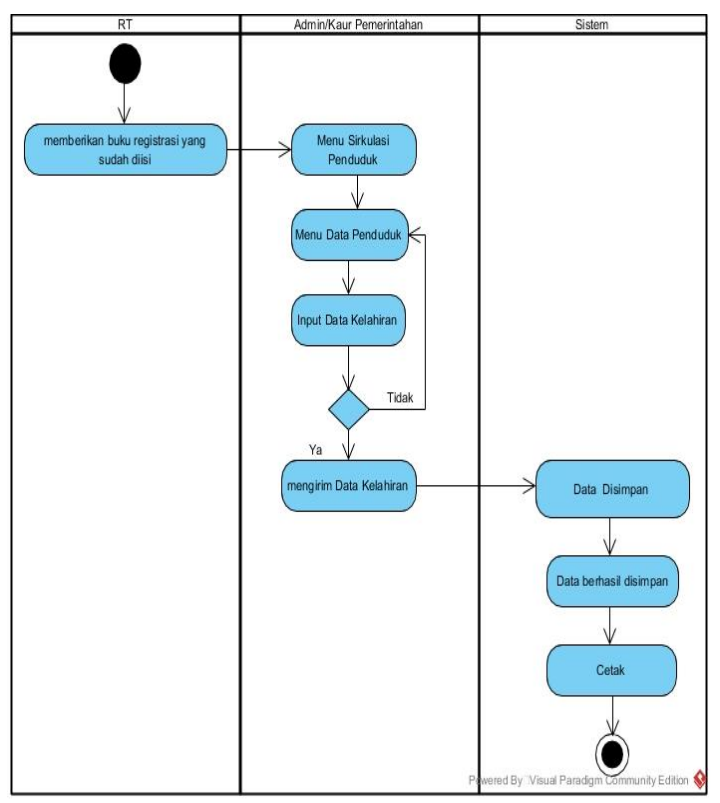

Gambar 9. Activity Diagram Data Kelahiran
RT memberikan buku registrasi yang sudah diisi keoada admin kemudian admin membuka menu sirkulasi penduduk, kemudian mengklik pada mendu data lahir, lalu menginput data lahir,jika benar maka data kelahiran tersebut dikirim ke database. Jika salah maka harus memeriksa kembali data kelahiran yang dimasukan pada menu kelola data. Kemudian data berhasil disimpan dan dapat mencetak laporan kelahiran.

\subsubsection{Activity Diagram Data Meninggal}

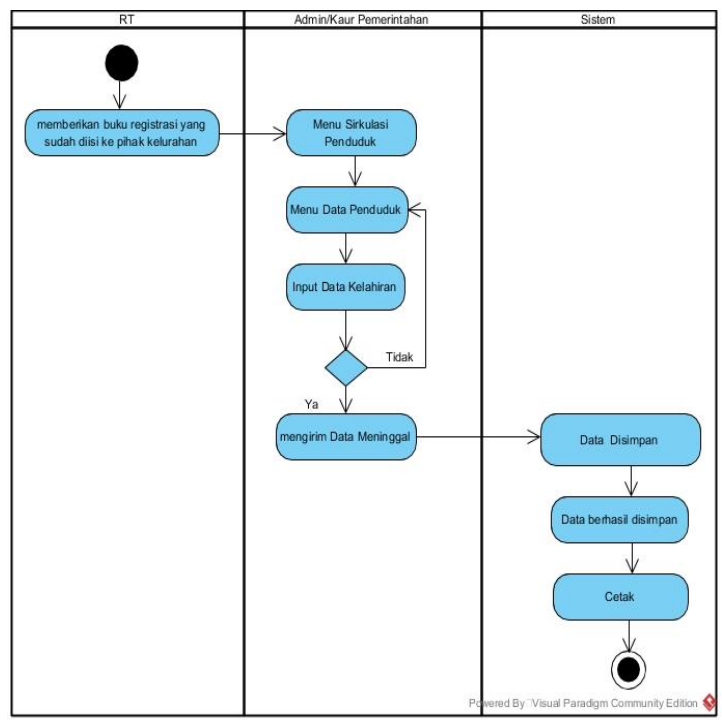

Gambar 10. Activity Diagram Data Meninggal

RT memberikan buku registrasi yang sudah diisi datanya kepada admin. Admin membuaka menu sirkulasi penduduk, dan mengklik menu data meninggal, lalu menginput data meninggal,jika benar maka data tersebut dikirm ke database untuk menyimpan. Jika salah maka harus memeriksa kembali data meninggal yang diinput pada menu data meninggal. Dan data tersebut dapat dicetak.

\subsubsection{Activity Diagram Data Pendatang}

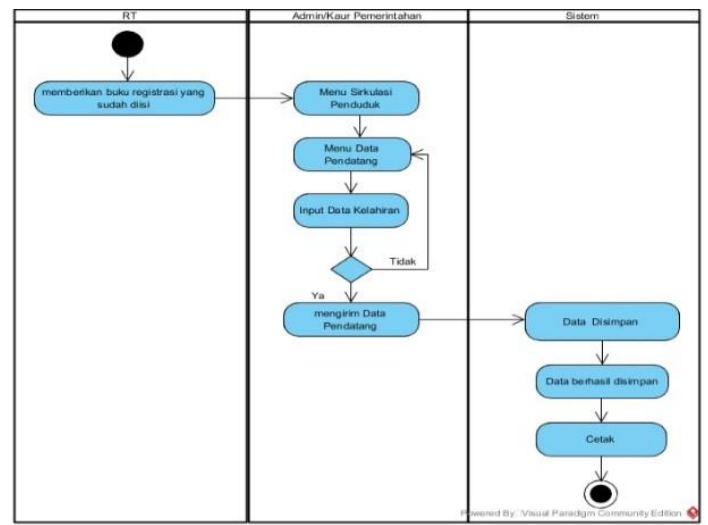

Gambar 11. Activity Diagram Data Pendatang

DOI: $10.54259 /$ satesi.v1i2.15

Lisensi: Creative Commons Attribution 4.0 International (CC BY 4.0) 
RT memberikan buku registrasi yang sudah diisi Penduduk meminta surat pengantar dari RT, setelah datanya kepada admin kemudian membuka menu penduduk menerima surat dari RT, penduduk sirkulasi penduduk, lalu mengklik pada menu data menerima surat dari RT, penduduk membawa FC pendatang, lalu menginput data. Jika benar maka KK/KTP dan surat pengantar dari RT ke pihak data tersebut dikrim ke database untuk disimpan kelurahan. Kemudian admin membuka menu kelola dan dapat dicetak. Jika salah maka harus memeriksa surat kemudian mengklik pada menu surat, kemudian kembali data yang diinput di menu data pendatang.

\subsection{Activity Diagram Data Data Pindah}

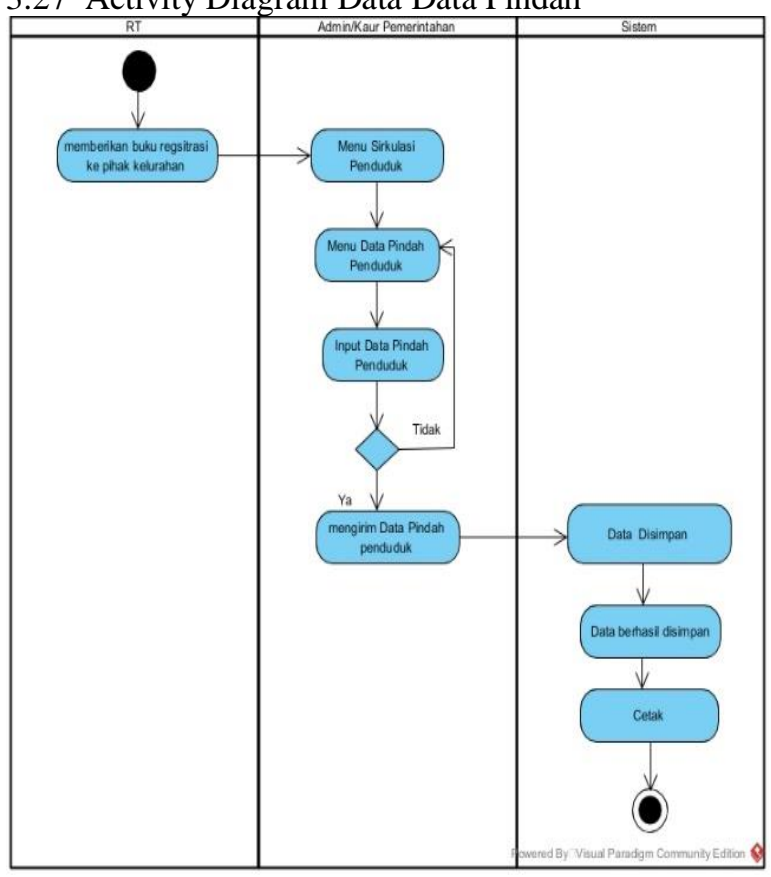

Gambar 12. Activity Diagram Data Pindah

RT memberikan buku registrasi kepada admin, kemudian admin membuka menu sirkulasi penduduk, kemudian mengkilik pada menu data pindah, lalu menginput data pindah, jika benar maka data pindah tersebut dikirim ke database untuk disimpan dan dapat dicetak. Jika salah maka harus memeriksa kembali data pindah yang dimasukan di menu data pindah.

\subsubsection{Activity Diagram Surat Domisili}

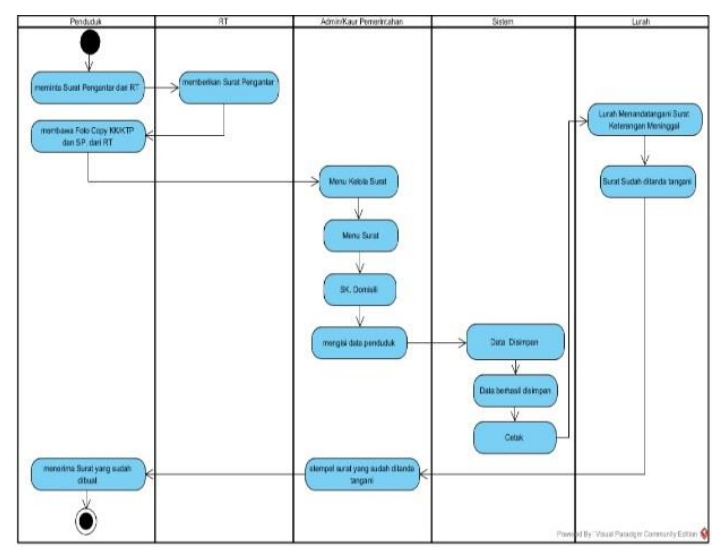

Gambar 13. Activity Diagram Surat Keterangan Domisili menginput data, jika benar maka data penduduk tersebut dikirm ke database untuk disimpan dan dapat menteknya. Jika salah maka harus memeriksa kembali surat yang diinput pada menu surat.

\subsubsection{Activity Diagram Surat Kelahiran}

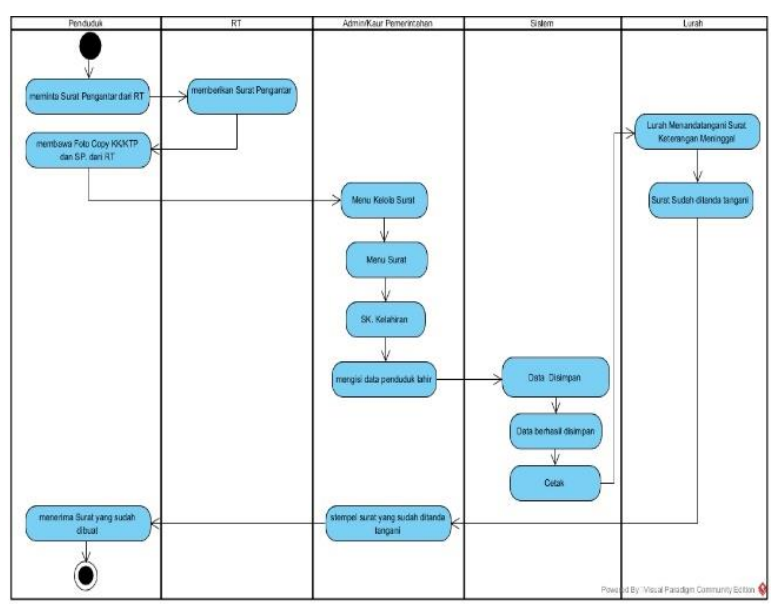

Gambar 14 Activity Diagram Surat Keterangan Kelahiran

Penduduk meminta surat pengantar dari RT, setelah penduduk menerima surat dari RT, penduduk membawa FC KK/KTP dan Surat Pengantar dari RT ke pihak kelurahan. Kemudian admin membuka pada menu kelola surat, kemudian mengklik pada menu surat, lalu menginput data kelahiran, apabila benar maka surat keterangan kelahiran tersebut dikirim kedatabase untuk disimpan. Jika saah makan kita memeriksa kembali surat yang diinput di menu surat.

\subsubsection{Activity Diagram Surat Keterangan Kematian}

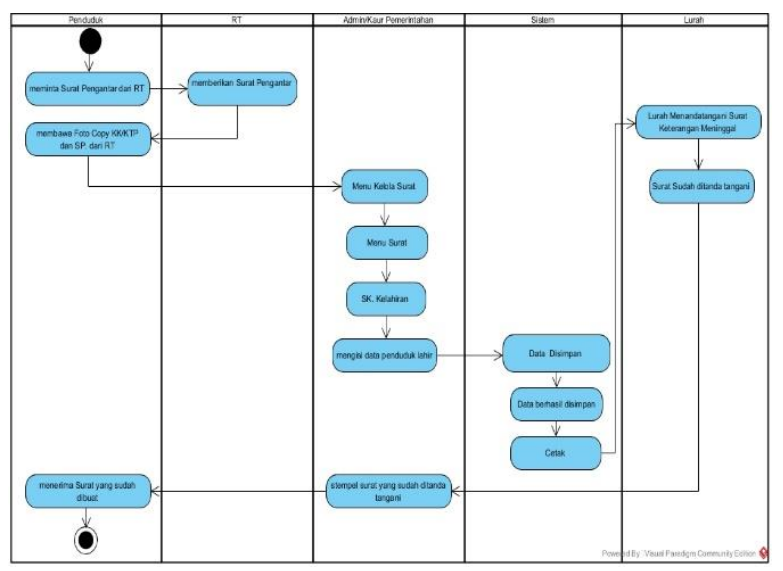

Gambar 15. Activity Diagram Surat Keterangan Kematian

DOI: $10.54259 /$ satesi.v1i2.15

Lisensi: Creative Commons Attribution 4.0 International (CC BY 4.0) 
Penduduk meminta surat pengantar dari RT, setelah membuka menu kolah surat, kemudian mengklik pada penduduk menerims surat dari RT, penduduk menu surat, lalu menginput data surat keterangan membawa FC KK/KTP dan Surat pengantar ke pihak pindah penduduk, jika benar maka data tersebut dikirm kelurahan. Kemudian admin pemerintahan membuka ke dstabase untuk disimpan. Jika salah maka kita menu kelola surat, kemudian mengklik pada menu memeriksa kembali suarat yang diinput di menu surat. surat, lalu menginput data, apabila benar maka data penduduk meninggal tersebut dikirm ke database untuk 3.3 Sequence Diagram disimpan. Jika salah maka kita memeriksa kembali surat yang dinout di menu surat.

\subsubsection{Activity Diagram Surat Keterangan Pendatang}

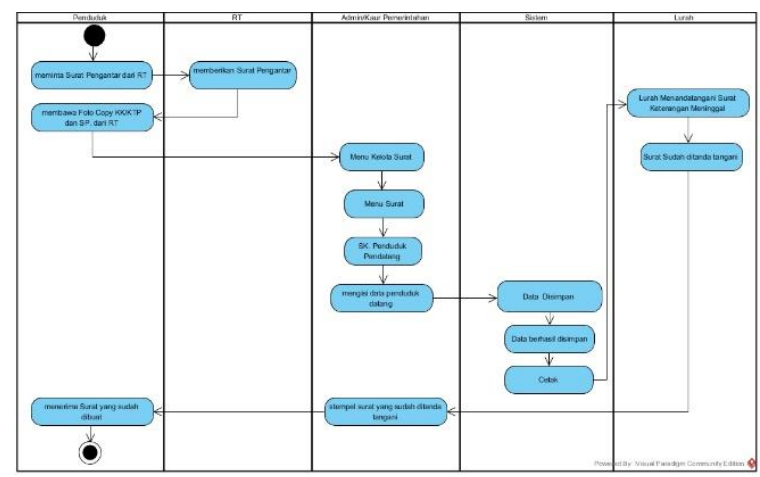

Gambar 16. Activity Diagram Surat Keterangan Pendatang

Penduduk meminta surat pengantar dari RT, setelah penduduk memerins surat dari RT, penduduk membawa FC KK/KTP dan surat pengantar dari RT ke pihak kelurahan. Kemudian admin membuka menu kelola surat, kemudian kengklik pada menu surat, lalu menginput data, jika benar maka data penduduk datang tersebut dikirim ke database untuk disimpan. Jika salah maka kita dapat memeriksa kembali surat yang diinput di menu surat.

\subsubsection{Activity Diagram Surat Keterangan Datang}

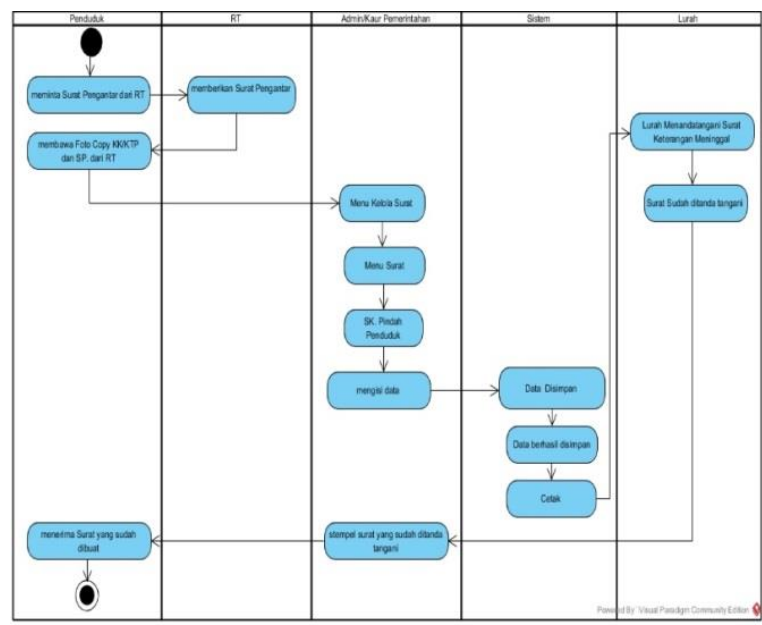

Gambar 17. Activity Diagram Surat Keterangan Pindah

Penduduk meminta surat pengatar dari RT, setelah penduduk membawa FC KK/KTP dan surat pengantar dari RT ke pihak kelurahan. Kemudian admin
Sequence diagram menggambarkan beberapa aktivitas dalam sebuah sistem yang dirancang, dapat dilihat sebagai berikut :

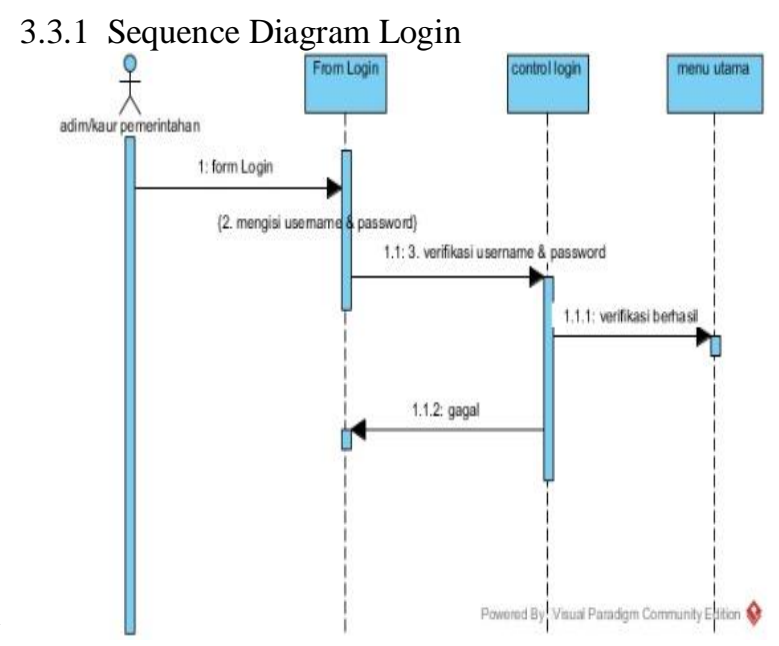

Gambar 18. Sequence Diagram Login

3.3.2 Sequense Diagram Data Penduduk/ KK

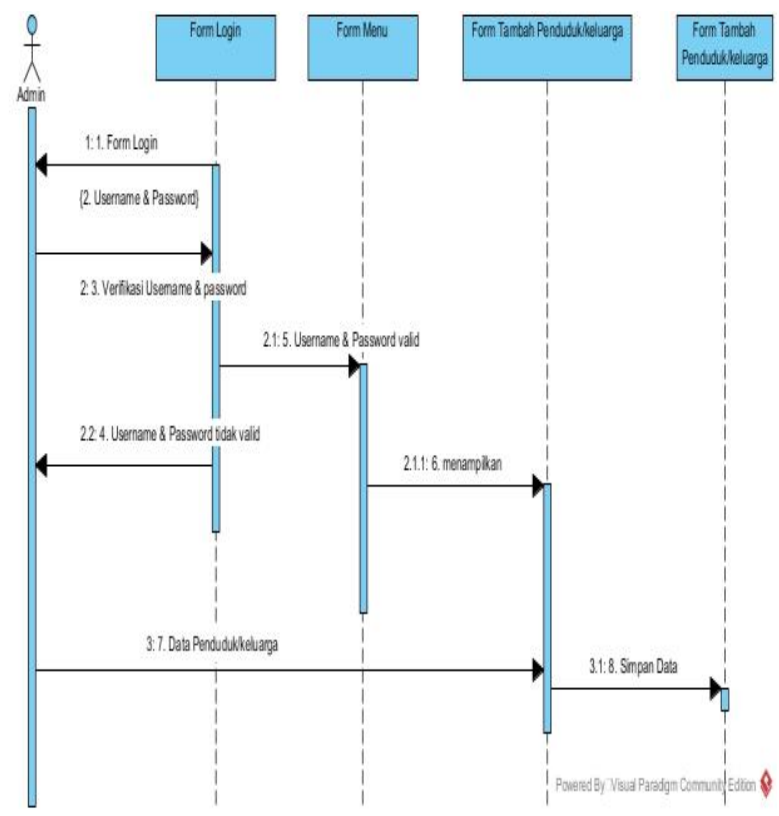

Gambar 19. Sequence Diagram Data Penduduk/Kartu Keluarga

DOI: $10.54259 /$ satesi.v1i2.15

Lisensi: Creative Commons Attribution 4.0 International (CC BY 4.0) 
3.3.3 Sequence Diagram Sirkulasi Penduduk (Data 3.3.5 Relasi Antar Tabel

Kelahiran, Data Meninggal, Data Pendatang dan Data Pindah Penduduk)

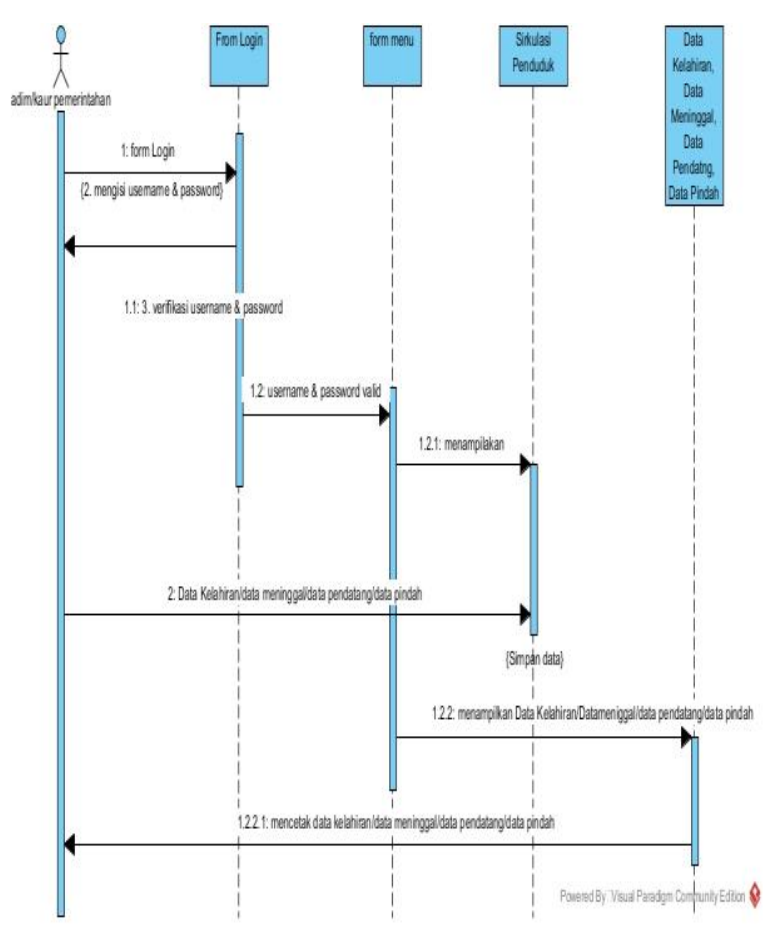

Gambar 20. Sequence Diagram sirkulasi Penduduk (Data Kelahiran, Data Meninggal, Data Pendatang, dan data Pindah

3.3.4 Sequence Diagram Surat Keterangan Domisili, Kelahiran, Kematian, Pendatang dan Pindah Penduduk.

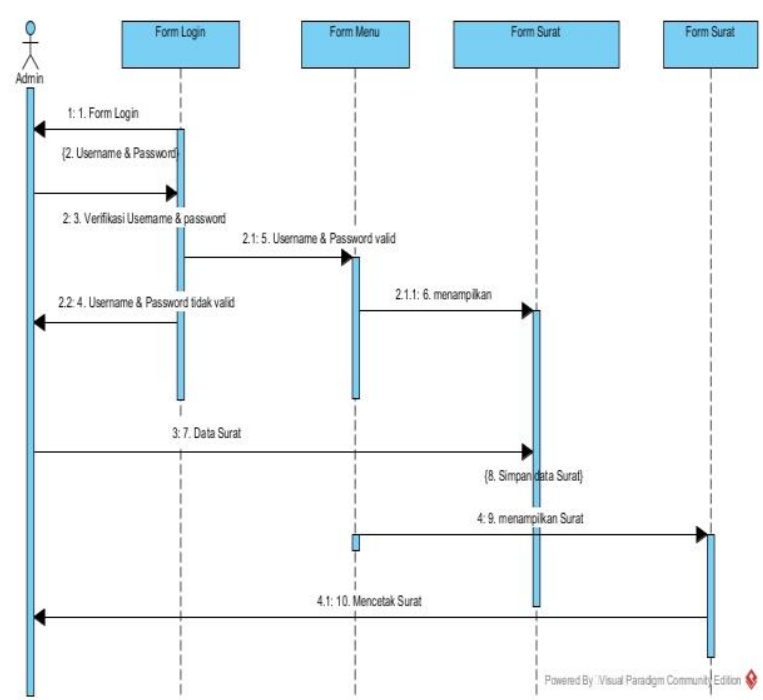

Gambar 21. Sequence Diagram Surat Keterangan Domisili, Kelahiran, Kematian, Pendatang dan Pindah

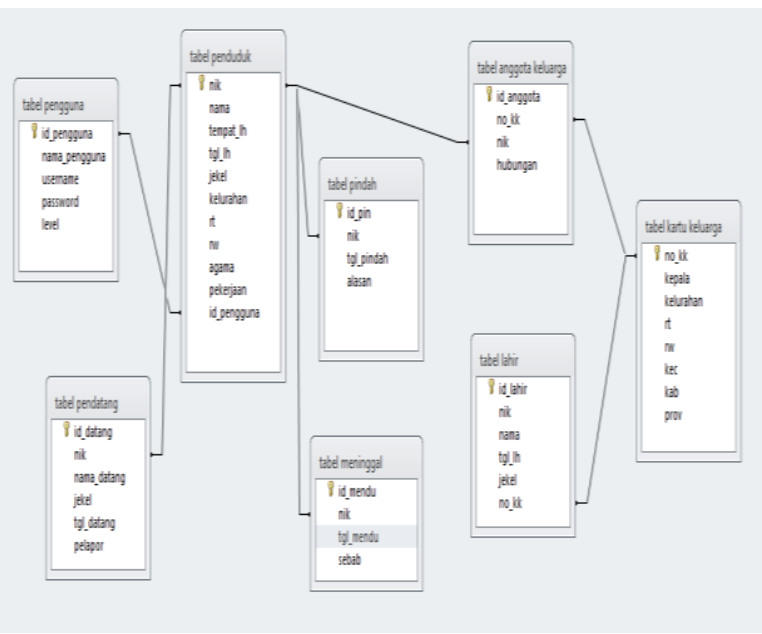

Gambar 22. Relasi Antar Tabel

Pada relasi tabel diatas merupakan gambaran relasi tabel-tabel dan penjelasan hubungan relasi antar tabel. Tabel pengguna mempunyai hubungan dengan tabel penduduk dengan relasi one to many. Tabel penduduk mepunyai hubungan dengan tabel pendatang, tabel pindah, tabel meninggal, dan tabel anggota keluarga denganrelasi one to many. Tabel kartu keluarga mempunyai hubungan dengan tabel lahir dan tabel anggota keluarga dengan relasi one to many.

\section{Pembahasan}

Implementasi adalah penerapan cara kerja sistem berdasarkan perancangan yang telah dibuat sebelumnya kedalam suatu bahasa pemograman tertentu. Tahap implementasi merupakan tahap penciptaan perangkat lunak, tahap kelanjutan dari kegiatan perancangan sistem. Tahap ini merupakan tahap dimana sistem siap untuk dioperasikan, yang terdiri dari penjelasan mengenai lingkungan implementasi dan implemntasi program.

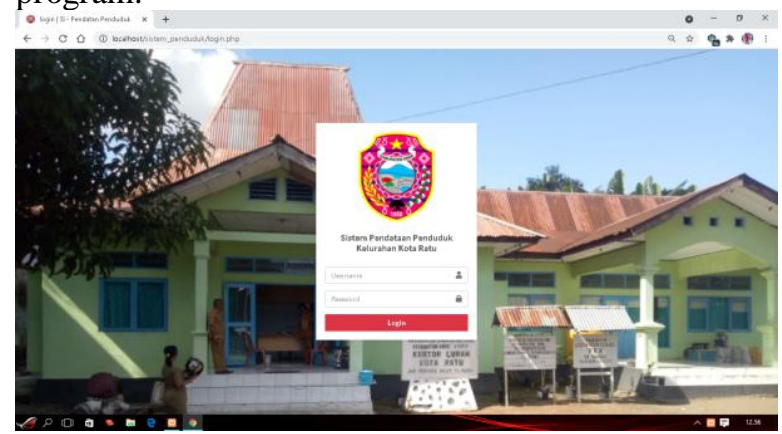

Gambar 23. Halaman Login Admin/Kaur Pemerintahan

Tampilan gambar diatas menjelaskan halaman login pertama kali dijalankan dimana admin harus memasukkan username dan password sebelum masuk ke halaman utama mengakses sistem yang telah dibuat.

DOI: $10.54259 /$ satesi.v1i2.15

Lisensi: Creative Commons Attribution 4.0 International (CC BY 4.0) 


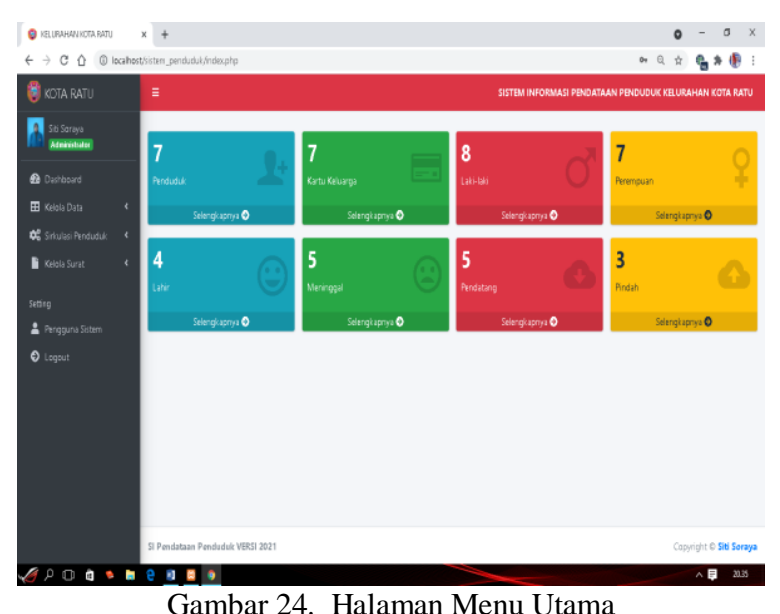

Seperti gambar diatas, menu untuk admin yang berisikan menu-menu kelola data, sirkulasi penduduk, kelola surat, pengguna sistem dan logout, dalam menumenu tersebut terdapat sub menu (data penduduk, data kartu keluarga, data lahir, data meninggal, data pendatang, data pindah, SK domisili, SK Kelahiran, SK kematian, SK pendatang dan SK Pindah).

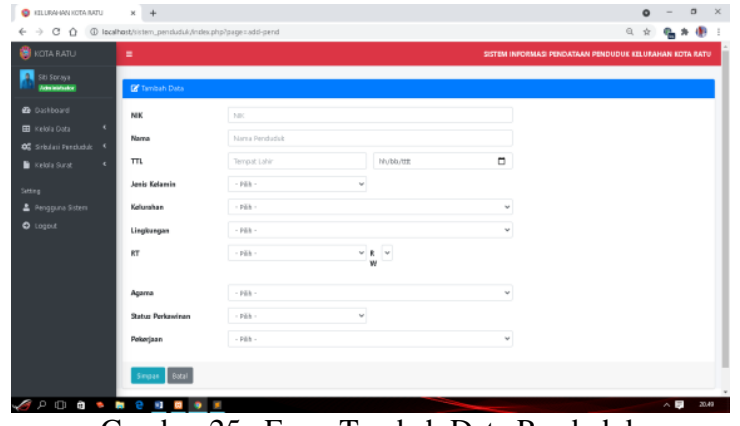

Gambar 25. Form Tambah Data Penduduk

Gambar diatas merupakan tampilan form input data penduduk, apabila ingin tambah data penduduk baru, pilih menu tambah data kemudian isi data pada form pengisian data penduduk kemudian klik menu simpan untuk menyimpan data penduduk baru ke database.

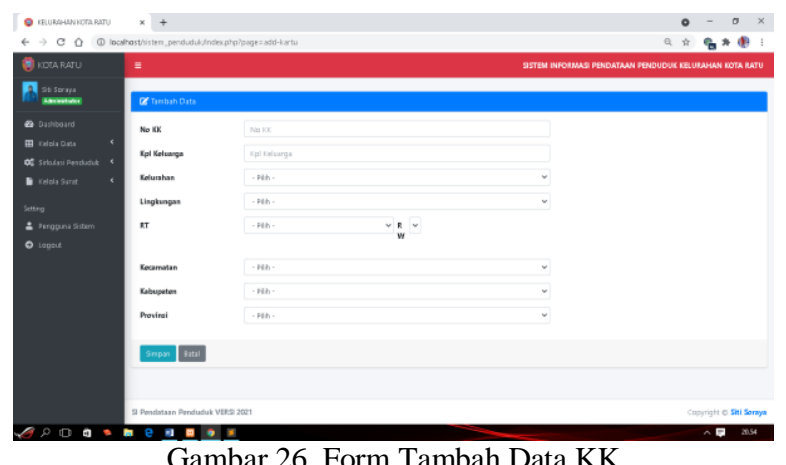

Seperti pada gambar diatas, tampilan form input data kartu keluarga sama halnya dengan penginputan data penduduk dengan mengisi form sesuai dengan fiel-filed yang tertera pada gambar diatas.

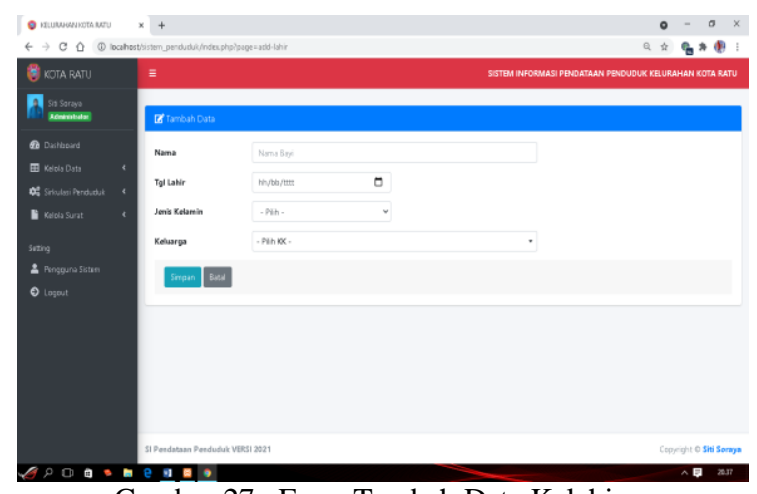

Gambar 27. Form Tambah Data Kelahiran

Tampilan form input tambah data kelahiran sama halnya dengan penginputan data kelahiran dengan mengisi form sesuai dengan fiel-fiel yangertera pada gambar diatas.

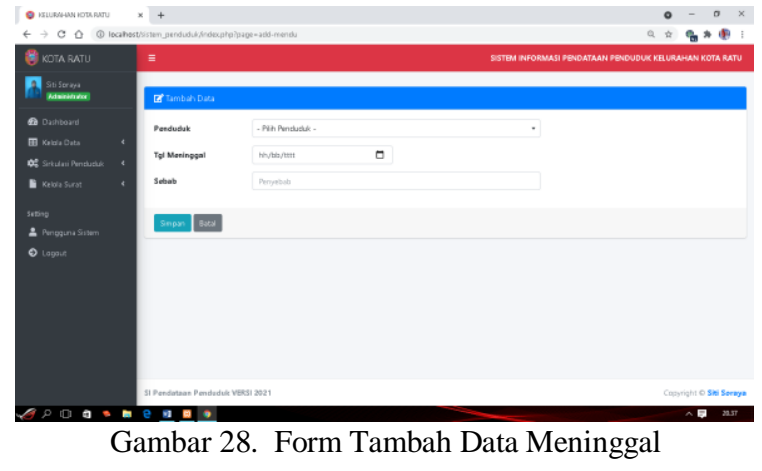

Gambar diatas, menjelaskan bentuk form input tabah data meninggal dengan cara mengisi form sesiau dengan format yang tertera pada gambar tersebut.

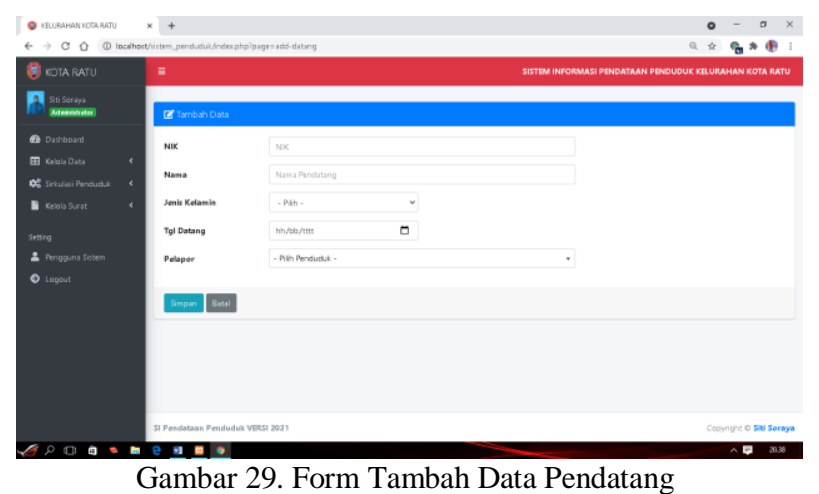

Tampilan gambar diatas merupakan form input tambah data pendatang dengan cara mengisi form sesuai dengan format yang tertera pada gambar.

DOI: $10.54259 /$ satesi.v1i2.15

Lisensi: Creative Commons Attribution 4.0 International (CC BY 4.0) 


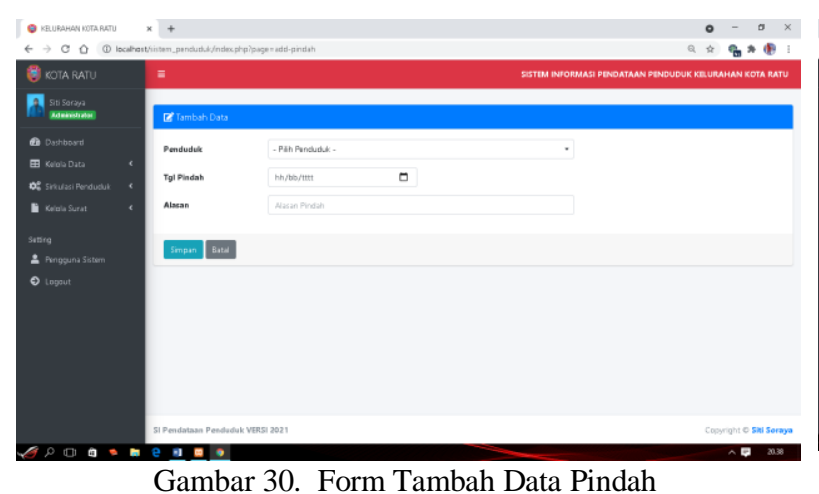

Gambar 30. Form Tambah Data Pindah

Gambar diatas, bentuk form input tambah data pindah dengan cara memasukan data sesuai dengan format yang tertera pada gambar diiatas.

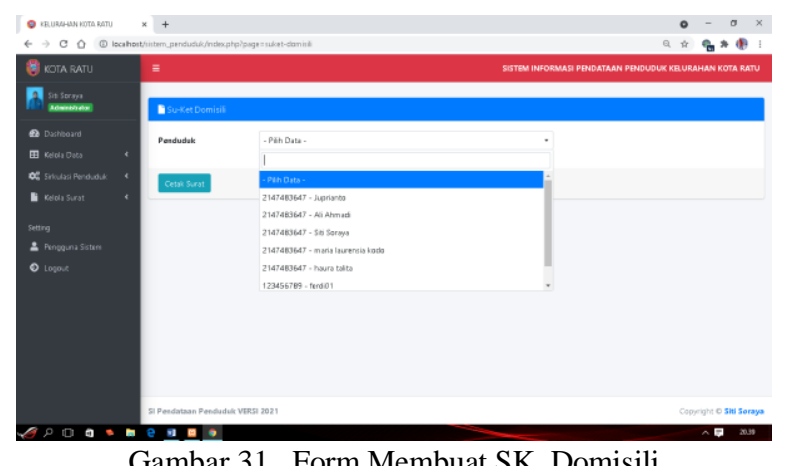

Gambar 31. Form Membuat SK. Domisili

Tampilan diatas merupakan form SK. Domisili dengan cara mencari nama penduduk kemudian klik di nama tersebut lalu klik pada menu cetak.

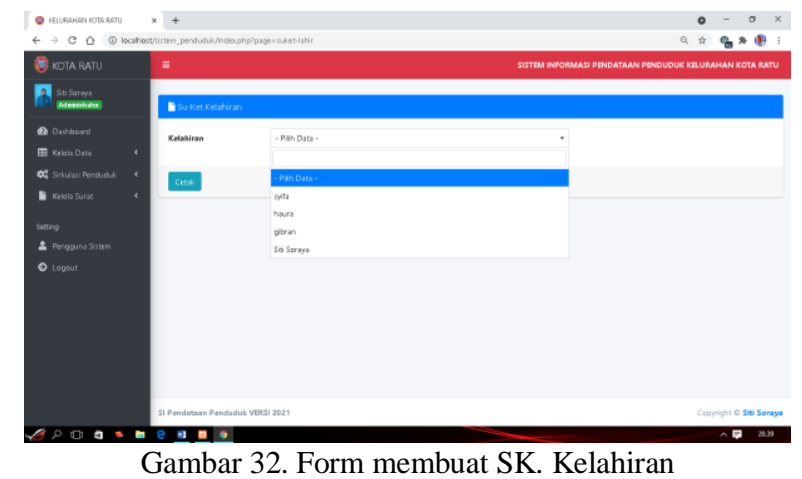

Gambar diatas merupakan form membuat SK. Kelahiran dengan cara mncari nama penduduk lahir kemudian klik dinama tersebut lalu klik pada menu cetak.

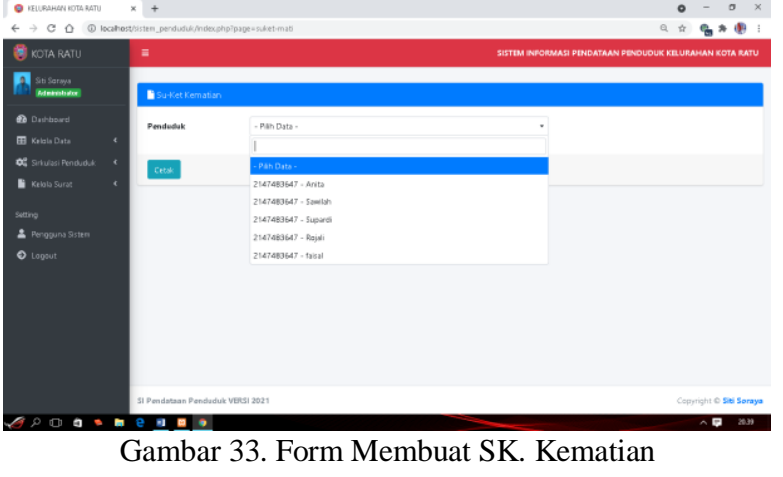

Tampilan diatas merupakan form membuat SK. Kematian. Dengan cara mencari nama penduduk kemudian klik di nama tersebut lalu klik pada menu cetak.

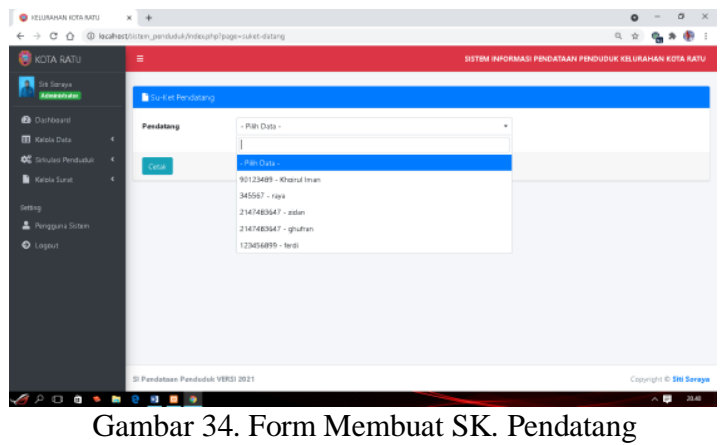

Gambar diatas merupakan form membuat SK. Pendatang dengan cara mencari nama penduduk pendatang yang dinput ssebelumya. Kemudian klik di nama tersebut lalu klik pada menu cetak.

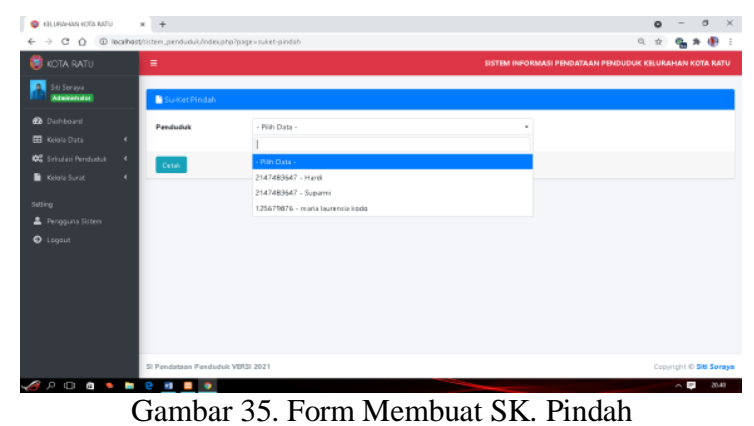

Gambar diatas merupakan form membuat SK. Pindah penduduk dengan cara mencari nama penduduk yang mau pindah kemudian mengklik di nama tersebut lalu klik pada menu cetak. 


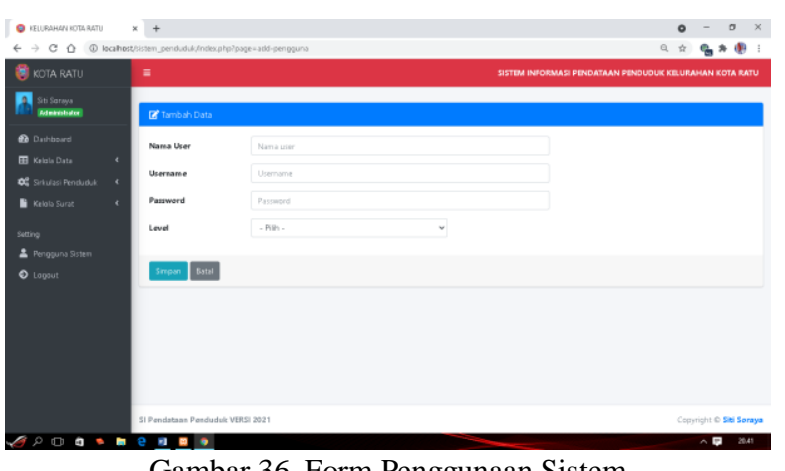

Gambar 36. Form Penggunaan Sistem

Tampilan diatas adalah form pengguna sistem. Dimana admin dapat menambah dan mengurangi pengguna sistem pada sistem tersebut. Ini hanya terdapat pada menu admin.

\section{Kesimpulan}

Rancang Bangun Sistem informasi pendataan penduduk ini merupakan salah satu solusi yang tepat bagi Kelurahan Kota Ratu Kabupaten Ende. Dari proses dan hasil peneitian ini, dapat disimpulkan bahwa sistem informasi pendataan penduduk dapat memudahkan dan membantu proses laporan penduduk kelurahan kota ratu, dapat menyajikan informasi secara depat dan efisien, karena sisitem ini dapat menginput data penduduk dan menyajikan laporan yang diperlukan oleh pihak kelurahan, data keseluruhan dapat tersimpan kedalam database yang akan menjadi arsip pihak kelurahan akan jauh lebih aman dibandingkan harus melakukan penyimpanan berkas laporan yang tidak efisien dan memungkinkan kerusakan dan kehilangan.

\section{Referensi}

[1] F. Haswan, "Perancangan Sistem Informasi Pendataan Penduduk Kelurahan Sungai Jering Berbasis Web Dengan Object Oriented Programming," J. Teknol. Dan Open Source, vol. 1, no. 2, pp. 92-100, 2018, doi: 10.36378/jtos.v1i2.23.

[2] B. Web and D. I. Kelurahan, "3 1,2,3," vol. 3, no. 2, pp. 342$348,2021$.

[3] Adianto, R. (2017). Rancang Bangun Aplikasi Pendataan Penduduk Pada Kecamatan Sungai Selan Berbasis Android dan Web. Teknik Informatika.

[4] Alawiyah, T., Hikmah, A. B., \& Simpony, B. K. (2019). Sistem Informasi Data Administrasi Penduduk E-SIDAPI. IJCIT (Indonesian Journal on Computer and Information Technology), 4(2), 189-195. https://doi.org/10.31294/ijcit.v4i2.5884

[5] Aprianti, W., \& Maliha, U. (2016). Sistem Informasi
Kepadatan Penduduk Kelurahan Atau Desa Studi Kasus Pada Kecamatan Bati-Bati. 2(2013), 21-28.

[6] Ardiansyah, D., Saepudin, A., Aryanti, R., \& Fitriani, E. (2020). Perancangan Sistem Informasi Akademik Madrasah Aliyah Negeri (Man) 4 Karawang Berbasis Web. Jurnal Teknologi Dan Open Source, 3(2), 187-201. https://doi.org/10.36378/jtos.v3i2.783

[7] Aris, A., Anggara, R., \& Zamzami, Z. A. (2016). Perancangan Sistem Informasi Penerimaan Siswa Baru Berbasis Web Pada PKBM Bhakti Sejahtera. Cices, 2(1), 87-98. https://doi.org/10.33050/cices.v2i1.215

[8] Arman, A. (2017). Sistem Informasi Pengolahan Data Penduduk Nagari Tanjung Lolo, Kecamatan Tanjung Gadang, Kabupaten Sijunjung Berbasis Web. Edik Informatika, 2(2), 163-170. https://doi.org/10.22202/ei.2016.v2i2.1459

[9] Candra, B., Arfyanti, I., Harianto, K., Informasi, S. S., Testing, B., Melak, K., Melak, R. F., Futsal, R., Sistem, M. S., Manajemen, I., \& Turnamen, P. (n.d.). SISTEM INFORMASI MANAJEMEN TURNAMEN FUTSAL BERBASIS WEB. 4753.

[10] Firman, A., Wowor, H. F., Najoan, X., Teknik, J., Fakultas, E., \& Unsrat, T. (2016). Sistem Informasi Perpustakaan Online Berbasis Web. E-Journal Teknik Elektro Dan Komputer, 5(2), 29-36.

[11] Informasi, J. S., Tinggi, S., \& Informatika, M. (2010). Berbasis Web Menggunakan Metode Waterfall Pada. Aprilia, 1, 1-8.

[12] Listia, B. A., Purnama, I., \& Harahap, S. Z. (2020). Perancangan Sistem Informasi Sensus Penduduk Berbasis Android Pada Desa Meranti. Journal of Computer Science and Information Systems, 1(1), 1. http://jurnal.ulb.ac.id/index.php/JCoInS/article/view/1842

13] Makassar, U. D., \& Mobile, A. (2021). Sistem Pengolahan Data Penduduk Pada Kantor Desa Bowong Cindea Kecamatan Bungoro Kabupaten Pangkajene Dan Kepulauan Berbasis Web. 88-97.

[14] Makmur, T. (2019). Teknologi Informasi: Dampak dan Implikasi Bagi Perpustakaan, Perpustakawan, serta Pemustaka. Perpustakaan Dan Ilmu Informasi, 1(1), 65.

[15] Munir, R. (2016). Algoritma Dan Pemrograman Dalam Bahasa Pascal, C, Dan C++ Edisi Keenam. Informatika. Bandung, 622.

[16] Pacitan, K., \& Timur, J. (2017). Menggunakan Framework Codeigniter Di Desa Ketanggung , Kecamatan Sudimoro ,.

[17] Pauziah, U. (2013). Perancangan Sistem Pendataan Penduduk Pada Kelurahan Cililitan Jakarta Timur Berbazis Delphi. Faktor Exacta 6(3): 189-199, 6(3), 189-199.

[18] Puastuti, D., \& Abb, K. S. (2017). Perancangan Sistem Informasi Pendataan Warga Sekolah Berbasis Web Pada Sdn 2 Pagelaran. Jpgmi, 3(1), 26-42.

[19] Saputro, H. M., Ariyani, L., \& Irawan, A. (2020). Rancangan Aplikasi Sistem Informasi Akademik Sekolah pada SMP Muttaqien Jakarta Berbasis Java. Jurnal Riset Dan Aplikasi Mahasiswa Informatika (JRAMI), 1(04), 483-489. https://doi.org/10.30998/jrami.v1i04.478

[20] SIDDIQ, M. H. (2018). Implementasi Sistem Informasi Penilaian Akademik Sekolah Menengah Pertama. https://dspace.uii.ac.id/handle/123456789/8830

[21] Supardin, D., \& Bunyamin, H. (2016). Aplikasi Pengelolaan Data Penduduk di Kantor Kelurahan Margawati. Jurnal $\begin{array}{lll}\text { Algoritma, } & \text { 12(2), 410-416. }\end{array}$ https://doi.org/10.33364/algoritma/v.12-2.410 